dàng đánh giá được tổn thương màng nhĩ.

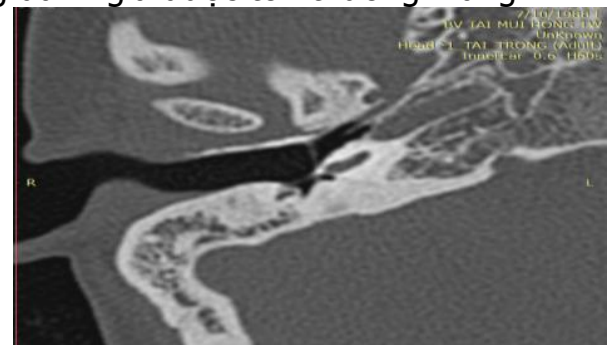

Hình 2. Bênh nhân 19007050, hình ảnh màng nhĩ chạm vào ụ nhô.

\section{KẾT LUÂ̂N}

Chụp CLVT xương thái dương trong bệnh lý xẹp nhĩ giúp xác định tình trạng màng nhĩ. Khi so sánh đối chiếu hình ảnh của tổn thương màng nhĩ trên CLVT với tổn thương màng nhĩ trên phẫu thuật, chúng tôi thây tỉ lệ chẩn đoán đúng của CLVT đối với sự thay đổi vị trí của màng nhĩ đạt từ $91.9 \%$ đến $97.3 \%$, trong đó CLVT có độ chính xác cao nhất $(97.3 \%)$ khi đánh giá hình thái màng nhĩ chạm ư nhô, CLVT có thể phát hiện và đánh giá được đáy túi co kéo và tổn thương tiều tường thượng nhĩ với độ chính xác 97.2\%.

\section{TÀI LIÊUU THAM KHẢO}

1. Mansour S, Magnan J, Haidar $H$, Nicolas $K$. Tympanic Membrane Retraction Pocket: Overview and Advances in Diagnosis and Management. Springer International Publishing; 2015. doi:10.1007/978-3-319-13996-8

2. Sadé J, Berco E. Atelectasis and secretory otitis media. Ann Otol Rhinol Laryngol. 1976:85(2 Supp 25 Pt 2):66-72. doi:10.1177/00034894760850S214

3. Nguyê̂n Lê Thủy. Hình thái lâm sàng của xẹp nhî qua nội soi tai bênh viên trương đai hoc y khoa Thái Nguyên. Tạp chí khoa học và cổng nghệ. 2015;134(04):163-168.

4. Nguyển Thị Thu Thư. Nghiên cứu đặc điểm lâm sàng và đánh giá chức năng tai giữa của xep nhĩ toàn bô giai đoan cuối. Luân văn tốt nghiệp bác sĩ nội trú Đại học Ỳ Hà Nội. 2016.

5. Hoàng Vũ Giang. Tìm hiểu đăcc điểm lâm sàng và đánh giá chức năng tai giữa của xẹp nhĩ tại bệnh viện Tai Mũi Họng Trung Ương. Luận văn thạc sĩ y hoc. 2003.

6. Khiếu Hữu Thanh. Nghiên cứu chức năng tai giữa trong các giai đoạn của xẹp nhĩ qua thính lực và nhĩ lượng. Luận văn thạc sĩ y học. 2012.

7. Maw AR, Hall AJ, Pothier DD, Gregory SP, Steer CD. The prevalence of tympanic membrane and related middle ear pathology in children: a large longitudinal cohort study followed from birth to age ten. Otol Neurotol. 2011;32(8):1256-1261. doi:10.1097/MAO.0b013e31822f10cf

8. Cao Minh Thành. Xẹp nhĩ: đặc điểm lâm sàng và điều trị. Tap chí Tai Mứi Hong Việt Nam. 57-7(1):3-8.

9. Tos $\dot{M}$, Poulsen G. Attic Retractions Following Secretory Otitis. Acta Oto-Laryngologica. $1980 ; 89(3-6): 479-486$

doi: $10.3109 / 00016488009127165$

\title{
CHĂM SÓC NGƯờI BÊNH NGÔ ĐộC CẤP Có THỞ MÁY TẠI TRUNG TÂM CHỐNG ĐộC BỆNH VIỆN BẠCH MAI NĂM 2020
}

\author{
Đặng Thị Quỳnh Hoa ${ }^{1,2}$, Nguyễn Đức Trọng ${ }^{2}$, Đặng Thị Xuân
}

TÓM TẮT

Muc tiêu: Đánh giá kết quả chăm sóc người bệnh ngộ độc cấp có thở máy tại Trung tâm Chống độc bệnh viện Bạch Mai và xác định một số yếu tố liển quan. Đối tượng và phương pháp: Nghiên cứu cắt ngang trên 135 người bệnh ngộ độc cấp có thở máy tại Trung tâm Chống độc Bệnh viện Bạch Mai từ tháng $01 / 2020$ đến 9/2020. Số liêu ghi nhân là kết hợp phiếu thu thập và chăm sóc người bệnh thở máy, bảng kiểm quy trình kỹ thuật và công cụ chăm sóc người bệnh. Kết quả: tỷ lệ người bệnh có kết quả chăm sóc tốt là $85,2 \%$. Bệnh nhân được chăm sóc vỗ rung liệu pháp hô hấp có khả năng kết quả chăm sóc tốt cao gấp 4,93 lần $(O R=4,93, p<0,05)$ so với việc

${ }^{1}$ Bênh viện Bach Mai Hà Nội, Hà nôi

2 Trường Đai hoc Thăng Long, Hà Nội

Chịu trách nhiểm chính: Đinh Thị Quỳnh Hoa

Email: hoaa9bachmai@gmail.com

Ngày nhâan bài: 8.01 .2021

Ngày phản biên khoa hoc: 9.3.2021

Ngày duyệt bài: 17.3.2021 không thực hiên vỗ rung. Chăm sóc cuff > 3 lần/ngày có khả nẳng kết quả chăm sóc tốt cao gấp 4,35 lần $(\mathrm{OR}=4,35, \mathrm{p}<0,05)$ so với việc chăm sóc với tần suất $\leq 3$ lần/ngày $(p<0,05)$. Kết luânn: chăm sóc điều dưỡng có vai trò rất quan trọng trong công tác chăm sóc người bệnh, đặc biệt ở người bệnh thở máy. Biện pháp vỗ rung, lý liệu pháp hô hấp và chăm sóc cuff cho kết quả chăm sóc tốt hơn.

Từ khóa: chăm sóc thở máy, ngộ độc cấp, điêu dưỡng

\section{SUMMARY}

CARING ACUTE POISONED PATIENTS

UNDER MECHANICAL VENTILATION AT BACH MAI HOSPITAL IN 2020

Objective: to evaluet the results of care for patients with acute poisoning under mechanical ventilation at Bach Mai Hospital Poison Control Center and identify related factors. Subjects and methods: A cross-sectional study of 135 patients with acute poisoning under mechanical ventilation admitted to the Poison Control Center, Bach Mai Hospital from $01 / 2020$ to $9 / 2020$. Observational data were recorded 
using a combination of collection and care sheets for patients under mechanical ventilation, checklists of procedures and tools used to care for patients. Results: The percentage of patients with good care was $85.2 \%$. Receiving vibrating pat for respiratory therapy was 4.93 times more likely to have good care ( $p$ <0.05) compared with not performing vibration. Cuff care $>3$ times/day was likely to be associated with good care $(O R=4.35)$ compared with care with frequency $\leq 3$ times/day $(p<0.05)$. Conclusions: Nursing care plays a very important role in patient care, especially in acute poisoned patients with mechanical ventilation. Vibration for respiratory therapy and cuff care were associated with better care results.

Keywords: care of mechanical ventilation, acute poisoning, nursing

\section{I. ĐẶT VẤN ĐỀ}

Ngộ độc cấp là một cấp cứu phổ biến ở trên thế giới và tại Viêt Nam. Hàng năm, trên thế giới ước tính có khoảng 200 triệu người tử vong do các nguyên nhân liên quan đến ngộ độc, tập trung chủ yếu ở các nước có thu nhập thấp và trung bình [1]. Tại Việt Nam, theo tônng kết của Bộ Y tế trong năm 2018, số bệnh nhân ngộ độc và tai nạn chấn thương chiếm $10 \%$ số ca mắc và $24,4 \%$ số tử vong trên toàn quốc [2]. Người bệnh ngộ độc cấp nặng có can thiệp thở máy ở các khoa Hồi sức tích cực và Chống độc, Khoa cấp cứu hầu hết là các bệnh nhân hồi sức phải can thiệp nhiều thủ thuật. Ngoài việc điều trị ngộ độc cấp, quá trình điều trị và chăm sóc cần chú ý đến các tổn thương thứ cấp khác như loét do tỳ đè, nhiễm trùng phổi, nhiễm trùng tiết niệu, teo cớ, cứng khớp, co rút cơ,... Việc chăm sóc các thương tật này cũng rất quan trọng trong quá trình điều trị ngộ độc cấp. Nếu không chăm sóc tốt, đúng quy trình kỹ thuật có thể người bệnh không thể phục hồi và mang thương tật suốt đời.

Vai trò của điều dưỡng trong chăm sóc toàn diện với những người bệnh điều trị ngộ độc cấp là hết sức quan trọng. Ở nước ta, các nghiên cứu trước đây chưa đề cập sâu đến quá trình chăm sóc điều dưỡng và điều trị người bệnh ngộ độc cấp trên quan điểm của điều dưỡng tại các khoa hồi sức cấp cứu và chống độc. Với mong muốn cải thiện tình trạng chăm sóc người bệnh ngộ độc cấp có thở máy, giúp nâng cao hiệu quả điêu trị, chúng tôi thực hiện đề tài này nhằm "Đánh giá kêt quả chăm sóc người bệnh ngộ độc cấp có thở máy tại Trung tâm Chống độc bệnh viện Bạch Mai và xác định một số yêu tố liên quan".

II. Đốl TƯỢNG VÀ PHƯƠNG PHÁP NGHIÊN CứU

2.1. Đối tượng nghiên cứu: Người bệnh ngộ độc cấp có thở máy điều trị tại Trung tâm
Chống độc, Bệnh viện Bạch Mai từ tháng 01/2020 đến 9/2020.

\section{- Tiêu chuẩn lưa chon:}

+ Người bệnh ngộ độc cấp: khi người bênh có $\geq 2 / 3$ tiêu chuẩn sau: (1) Có tiếp xúc với chất độc; (2) Có biểu hiện lâm sàng của ngộ độc; (3) Xét nghiệm thấy chất độc trong dịch dạ dày, nước tiểu, máu

+ Người bênh có thở máy

- Tiêu chuẩn loại trư:

+ Người bệnh không phải do ngộ độc

+ Người bểnh và gia đình không đồng ý tham gia nghiên cứu.

\subsection{Phương pháp nghiên cứu.}

2.2.1. Thiết kế nghiên cứu: nghiên cứu mô tả cắt ngang

2.2.2. Cỡ mẫu và phương pháp chon mẫu: Sử dụng công thức ước tính cỡ mẫu cho một tỷ lệ với độ chính xác tương đối:

$$
\mathrm{n}=\mathrm{Z}^{2}(1-\mathrm{a} / 2) \frac{\mathrm{p}(1-\mathrm{p})}{\varepsilon^{2} \mathrm{p}}
$$

Trong đó: $\mathrm{n}$ : cõ mẫu cần tính cho nghiên cứu; $Z=$ hệ số tin cậy, với mức ý nghĩa $a=0,05$ hệ số tin cậy $z=1,96 ; p=41 \%$ theo nghiên cứu của Phạm Thanh Hải năm 2018 [5]; $\varepsilon$ : sai số tương đối, chọn $\varepsilon=0,2$. Cõ̃ mẫu cần thiết là 135. Tiến hành chọn mẫu thuận tiện, toàn bộ người bệnh ngộ độc phải thở máy đủ tiêu chuẩn nghiên cứu.

2.2.3. Tiến hành nghiên cứu và thu thập số liệu:

- Số liệu được ghi chép thống nhất theo mẫu "Phiếu theo dõi người bệnh có thở máy". Nhóm nghiên cứu tiến hành quan sát và điền vào bảng kiểm quy trình kỹ thuật, ghi chép các thông tin trước, trong và sau chăm sóc, lâm sàng và xét nghiệm vào phiếu theo dõi.

- Đánh giá các chỉ số ngay khi có chỉ định thở máy xâm nhập và trong quá trình điều trị:

+ Các dấu hiệu sinh tồn, biểu hiện lâm sàng

+ Các kỹ thuật điều dưỡng thực hiện trong từng ngày làm việc:

Đánh giá: cuff, ống thông cho ăn, hút đờm.

Chăm sóc ống thông cho ăn

Chăm sóc chân ống mở khí quản/nôi khí quản (MKQ/NKQ), số lần chăm sóc cuff, ống NKQ/MKQ, hê thống dây dẫn của máy thở, bẫy nước, bình hút đờm trên người bệnh thở máy có xâm nhập $\geq 2$ lần/ngày và <2 lần/ngày.

Chăm sóc ống thông tiểu $\geq 2$ lân/ngày và $<2$ lần/ngày. Vệ sinh răng miệng, mũi, mắt, lau người 1 lần/ngày và $\geq 2$ lần/ngày bằng các dung dịch sát khuẩn

+ Đánh giá kết quả chăm sóc theo các mức [7]: 
- Tốt: Tất cả các triệu chứng lâm sàng đều thuyên giảm $\geq 80 \%$, người bệnh tỉnh (thôi hoặc cai thở máy), không bị nhiễm khuẩn bệnh viện. Ra viện hoặc chuyển viện về tuyến dưới.

- Khá: Các triệu chứng lâm sàng đều cải thiện > 50 đến $70 \%$, người bệnh tỉnh (cai thở máy), không bị nhiễm khuẩn bệnh viện. Ra viện hoặc chuyển viện về tuyến dưới.

- Trung bình: Các triệu chứng lâm sàng cải thiện > 30 đến 40\%, không bị nhiễm khuẩn bệnh viện. Ra viện hoặc chuyển viện về tuyến dưới.

- Kém: Các triệu chứng lâm sàng đều cải thiện < 30\%, có biến chứng, bị nhiểm khuẩn bệnh viện (hoặc tử vong do bệnh quá nặng).

2.3. Xử lý số liệu: Kết quả được làm sạch, mã hóa và nhập bắng phần mềm Epidata 3.1. Mô hình phân tích hồi quy logistic đa biến được

thực hiện nhằm mối liên quan giữa kết quả chăm sóc và điều trị chung với các yếu tố chăm sóc, khác biệt có ý nghĩa thống kê khi $p<0,05$.

2.4. Đạo đức nghiên cứu: Nghiên cứu tuân thủ theo quy tắc đạo đức trong nghiên cứu $y$ sinh học, chỉ nhằm bảo vệ và nâng cao sức khỏe cho người bệnh, thông tin của người bệnh được giữ kín. Đề cương nghiên cứu được Hội đồng thông qua đề cương nghiên cứu trước khi được tiến hành.

\section{KẾT QUẢ NGHIÊN CỨU}

Nghiên cứu tiến hành trên 135 người bệnh ngộ độc cấp thở máy. Nam giới là 81/135 BN (60,0\%). Tuổi trung bình là 46,6 $\pm 16,9$ tuổi $(12-93)$.

\subsection{Hoạt động chăm sóc}

Bảng 1. Chăm sóc miệng, vêt trợt/loét da, vỗ rung, nằm đệm hơi, thay dây truyền

\begin{tabular}{|c|c|c|c|c|c|}
\hline Thời điếm & $\begin{array}{c}\text { Ngày 1 } \\
(135 \text { NB) }\end{array}$ & $\begin{array}{c}\text { Ngày } 2 \\
(135 \text { NB) }\end{array}$ & $\begin{array}{c}\text { Ngày } 5 \\
(109 \text { NB) }\end{array}$ & $\begin{array}{l}\text { Ngày } 7 \\
\text { (75 NB) }\end{array}$ & $\begin{array}{c}\text { Ra viện/ } \\
\text { chuyển khoa } \\
\text { (135 NB) }\end{array}$ \\
\hline & $(n, \%)$ & $(n, \%)$ & $(n, \%)$ & $(n, \%)$ & $(n, \%)$ \\
\hline \multicolumn{6}{|c|}{ Chăm sóc răng miệng } \\
\hline 1 lần/ngày & $106(78,5)$ & $103(76,3)$ & $85(78,0)$ & $55(73,3)$ & $102(75,6)$ \\
\hline$\geq 2$ lần/ngày & $29(21,5)$ & $32(23,7)$ & $24(22,0)$ & $20(26,7)$ & $33(24,4)$ \\
\hline \multicolumn{6}{|c|}{ Chăm sóc vềt trợt, loét da } \\
\hline$\leq 2$ lần/ngày & $8(5,8)$ & $12(8,9)$ & $13(11,9)$ & $9(12,0)$ & $5(3,7)$ \\
\hline > 2 lần/ngày & $6(4,4)$ & $11(8,1)$ & $10(9,2)$ & $7(9,3)$ & $7(5,2)$ \\
\hline Không loét/không thực hiện & $121(89,8)$ & $112(83,0)$ & $86(78,9)$ & $59(78,7)$ & $124(91,9)$ \\
\hline \multicolumn{6}{|c|}{ Vố rung liệu pháp hô hấp } \\
\hline Thực hiện 2h/lần & $95(70,4)$ & $100(74,1)$ & $92(84,4)$ & $71(94,7)$ & $128(94,8)$ \\
\hline Không & $40(29,6)$ & $35(25,9)$ & $17(15,5)$ & $5(5,3)$ & $7(5,2)$ \\
\hline \multicolumn{6}{|c|}{ Năm đệm hơi } \\
\hline Có & $123(91,1)$ & $126(93,3)$ & $107(98,2)$ & $72(96,0)$ & $129(95,6)$ \\
\hline Không & $12(8,9)$ & $9(6,7)$ & $2(1,8)$ & $3(4,0)$ & $6(4,4)$ \\
\hline \multicolumn{6}{|c|}{ Thay dây truyền, nối ba trạc } \\
\hline Có & $129(95,6)$ & $126(93,3)$ & $101(92,6)$ & $73(97,3)$ & $127(94,1)$ \\
\hline Không & $6(4,4)$ & $9(6,7)$ & $8(7,4)$ & $2(2,7)$ & $8 \quad(5,9)$ \\
\hline
\end{tabular}

Nhận xét: - Chăm sóc răng miệng 1 lần/ngày (78,5\% lúc vào viện và $75,6 \%$ lúc ra viện). Có $10,2 \%$ NB cần chăm sóc vết loét da, trong đó $4,4 \%$ được chăm sóc $>2$ lần/ngày, không cần chăm sóc loét da khi ra viên là $91,9 \%$.

- Vỗ rung liệu pháp hô hấp $2 \mathrm{~h} /$ /ần: ngày đầu là $70,4 \%$, tăng lên $94,8 \%$ khi ra viện/chuyển khoa (RV/CK). Thay dây truyền nối ba trạc là $95,6 \%$ khi vào viện và $94,1 \%$ khi $R V / C K$.

Bảng 2. Hoạt động chăm sóc cho người bệnh khì thở máy

\begin{tabular}{|c|c|c|c|c|c|}
\hline \multirow[t]{2}{*}{ Hoạt động } & $\begin{array}{c}\text { Ngày 1 } \\
(135 \text { NB) }\end{array}$ & $\begin{array}{c}\text { Ngày 2 } \\
\text { (135 NB) }\end{array}$ & $\begin{array}{c}\text { Ngày 5 } \\
\text { (109 NB) }\end{array}$ & $\begin{array}{l}\text { Ngày } 7 \\
\text { (75 NB) }\end{array}$ & $\begin{array}{c}\text { Ra viện/chuyến } \\
\text { khoa(135 NB) }\end{array}$ \\
\hline & $(n, \%)$ & $(n, \%)$ & $(n, \%)$ & $(n, \%)$ & $(\mathbf{n}, \%)$ \\
\hline \multicolumn{6}{|c|}{ Chăm sóc thay băng ống NKQ/MKQ } \\
\hline$\leq 2$ lần/ngày & $109(80,7)$ & $119(88,1)$ & $101(92,7)$ & $62(82,7)$ & $42(31,1)$ \\
\hline$>2$ lần/ngày & $26(19,3)$ & $16(11,9)$ & $8(7,3)$ & $13(17,3)$ & $93(68,9)$ \\
\hline \multicolumn{6}{|c|}{ Theo dõi vị trí NKQ/MKQ } \\
\hline$\leq 2$ lần/ngày & $8(5,9)$ & $12(8,9)$ & $13(11,9)$ & $8(10,7)$ & $9(6,7)$ \\
\hline$>3$ lần/ngày & $127(94,1)$ & $123(91,1)$ & $96(88,1)$ & $67(89,3)$ & $126(93,3)$ \\
\hline
\end{tabular}




\begin{tabular}{|c|c|c|c|c|c|}
\hline \multicolumn{6}{|c|}{ Hút đờm } \\
\hline$\leq 3 \mathrm{~h}$ /lần & $9(6,7)$ & $11(8,1)$ & $12(11,0)$ & $10(13,3)$ & $12(8,9)$ \\
\hline > 4h /lần & $126(93,3)$ & $124(91,9)$ & $97(89,0)$ & $65(86,7)$ & $123(91,1)$ \\
\hline \multicolumn{6}{|c|}{ Số lần chăm sóc cuff } \\
\hline$\leq 3$ lần/ngày & $16(11,9)$ & $17(12,6)$ & $15(13,8)$ & $9(12,0)$ & $13(9,0)$ \\
\hline > 3 lần/ngày & $119(88,1)$ & $118(87,4)$ & $94(86,2)$ & $66(88,0)$ & $122(90,4)$ \\
\hline \multicolumn{6}{|c|}{ Theo dối áp lực hút trên Cuff } \\
\hline Có & $91(67,4)$ & $93(68,9)$ & $75(68,8)$ & $56(74,7)$ & $114(84,4)$ \\
\hline Không & $44(32,6)$ & $42(31,1)$ & $34(31,2)$ & $19(25,3)$ & $21(15,6)$ \\
\hline \multicolumn{6}{|c|}{ Số lần chăm sóc dây dân máy thở, bây nước } \\
\hline 2 lần/ngày & $6(4,4)$ & $10(7,4)$ & $9(8,3)$ & $6(8,0)$ & $10(7,4)$ \\
\hline$>3$ lần/ngày & $129(95,6)$ & $125(92,6)$ & $100(91,7)$ & $69(92,0)$ & $1252,6)$ \\
\hline
\end{tabular}

Nhận xét: - Chăm sóc thay băng ống NKQ/MKQ $\leq 2$ lần/ngày là $80,7 \%$ ở ngày đầu và $82,7 \%$ ở ngày thứ 7 . Có $94,1 \%$ được theo dõi vị trí $\mathrm{NKQ} / \mathrm{MKQ}>3$ lần/ngày đầu và $89,3 \%$ ở ngày thứ 7 .

-Có $93,3 \%$ NB hút đờm $>4$ h/lần ở ngày đâuu và giảm còn $86,7 \%$ ngày thứ 7 . Chăm sóc cuff $>3$ lần/ngày là $88,1 \%$ khi vào viện và $88,0 \%$ ở ngày thứ 7 . Có $67,4 \%$ NB được theo dõi áp lực hút trên cuff lúc vào viện và ngày 7 là $74,7 \%$. Số lần chăm sóc dây dẫn máy thở, bẫy nước $>3$ lần/ngày ở ngày đầu là $95,6 \%$ và $92,0 \%$ ngày thứ 7 .

Bảng 3. Hoạt động chăm sóc dinh dưỡng, thực hiện thủ thuật cho người bệnh và giáo dục sức khóe cho người bệnh và gia đình

\begin{tabular}{|c|c|c|c|c|c|}
\hline \multirow[t]{2}{*}{ Hoạt động } & $\begin{array}{c}\text { Ngày 1 } \\
(135 \text { NB) }\end{array}$ & $\begin{array}{c}\text { Ngày } \mathbf{2} \\
(135 \text { NB) }\end{array}$ & $\begin{array}{c}\text { Ngày } \mathbf{5} \\
(109 \text { NB) }\end{array}$ & $\begin{array}{l}\text { Ngày } 7 \\
\text { (75 NB) }\end{array}$ & $\begin{array}{c}\text { Ra viện/ } \\
\text { chuyển khoa } \\
(135 \text { NB) }\end{array}$ \\
\hline & $(n, \%)$ & $(n, \%)$ & $(n, \%)$ & $(\mathbf{n}, \%)$ & $(n, \%)$ \\
\hline \multicolumn{6}{|c|}{ Số lần chăm sóc chân ống thông cho ăn, đối vị trí cố định } \\
\hline 1 lần/ngày & $118(86,7)$ & $109(80,7)$ & $88(80,7)$ & $67(89,3)$ & $126(92,6)$ \\
\hline$>2$ lần/ngày & $17(13,3)$ & $26(19,3)$ & $21(19,3)$ & $8(10,7)$ & $9(7,4)$ \\
\hline \multicolumn{6}{|c|}{ Cho người bệnh ăn nhỏ giọt qua ống thông dạ dày } \\
\hline 5 - 6 lần /ngày & $46(34,1)$ & $55(40,7)$ & $64(58,7)$ & $52(69,3)$ & $72(53,3)$ \\
\hline 2- 4 lần/nqày & $54(40,0)$ & $51(37,8)$ & $22(20,2)$ & $12(16,0)$ & $53(39,3)$ \\
\hline Nhịn ăn & $35(25,9)$ & $29(21,5)$ & $23(21,1)$ & $11(14,7)$ & $10(7,4)$ \\
\hline \multicolumn{6}{|c|}{ Tình trạng thông thoáng đường truyên } \\
\hline Thông tốt & $134(99,3)$ & $134(99,3)$ & $109(100)$ & $75(100)$ & $135(100)$ \\
\hline Tằ & $1(0,7)$ & $1(0,7)$ & $0(0,0)$ & $0(0,0)$ & $0(0,0)$ \\
\hline \multicolumn{6}{|c|}{ Tình trạng vệ sinh băng ven truyên } \\
\hline Băng sach, chắc, không viêm & $133(98,5)$ & $134(99,3)$ & $103(94,5)$ & $74(98,7)$ & $134(99,3)$ \\
\hline Bẩn, chạc ba mất nắp & $2(1,5)$ & $1(0,7)$ & $6(5,5)$ & $1(1,3)$ & $1(0,7)$ \\
\hline \multicolumn{6}{|c|}{ GDSK cho gia đình người bệnh về tình trạng bệnh, kiên thức phòng chống ngộ độc } \\
\hline 1 lần/ngày & $21(15,6)$ & $13(9,6)$ & $9(6,9)$ & $5(6,7)$ & $6(4,4)$ \\
\hline > 2 lần/ngày & $114(84,4)$ & $122(90,4)$ & $100(93,1)$ & $70(93,3)$ & $129(95,6)$ \\
\hline \multicolumn{6}{|c|}{ GDSK cho gia đình người bệnh về chế độ dinh dưỡng } \\
\hline 1 lần/ngày & $29(21,5)$ & $25(18,5)$ & $19(14,7)$ & $9(12,0)$ & $12(5,1)$ \\
\hline$>2$ lần/ngày & $106(78,5)$ & $110(81,5)$ & $90(82,6)$ & $66(88)$ & $123(94,9)$ \\
\hline \multicolumn{6}{|c|}{ GDSK cho gia đình người bệnh về nội quy bệnh viện } \\
\hline 1 lần/ngày & $12(8,9)$ & $11(8,2)$ & $4(3,1)$ & $3(4,0)$ & $4(2,9)$ \\
\hline$>2$ lần/ngày & $123(91,2)$ & $124(91,9)$ & $105(96,9)$ & $72(96,0)$ & $131(97,1)$ \\
\hline
\end{tabular}

Nhân xét: - Chăm sóc NB: chăm sóc chân ống thông cho ăn nhỏ giọt và đổi vị trí cố định 1 lần/ngày là $86,7 \%$ ngày đầu và $89,3 \%$ vào ngày thứ 7. Có 40,0\% NB được cho ăn 2- 4 lần/ngày ngày đầu và $16,0 \%$ vào ngày 7 . Tỷ lệ ăn $5-6$ lần/ngày ngày đâu là $34,1 \%$ và tăng $69,3 \%$ ngày 7 . Có $99,3 \%$ NB có đường truyền thông tốt và băng ven truyền sạch, chắc.

- GDSK cho gia đình NB: về tình trạng bệnh, kiên thức phòng chống ngộ độc $>2$ lần/ngày với tỷ lệ cao là $84,4 \%$ ngày đầu và $95,6 \%$ khi RV/CK; về dinh dương > 2 lần/ngày là $78,5 \%$ và $94,9 \%$ khi $R V / C K$; về nội quy bệnh viện > 2lần/ngày là $91,2 \%$ và $97,1 \%$. 
3.2. Kết quả chăm sóc và các yếu tố liên quan. Sau quá trình chăm sóc, tại thời điểm ra viện/chuyển khoa có $85,2 \%$ đối tượng có kết quả chăm sóc tốt và 14,8\% đối tượng được chăm sóc chưa tốt.

Bảng 4. Yếu tố liên quan tới kêt quả chăm sóc

\begin{tabular}{|c|c|c|c|}
\hline $\begin{array}{c}\text { Yếu tố trong mô } \\
\text { hình }\end{array}$ & OR & \begin{tabular}{|c|} 
CI \\
$95,0 \%$ \\
\end{tabular} & $\mathbf{P}$ \\
\hline \multicolumn{4}{|c|}{ Chăm sóc ống NKQ/MKQ } \\
\hline$\leq 2$ lần/ngày $(*)$ & 1 & & - \\
\hline$>2$ lần/ngày & 0,40 & $0,033-4,95$ & 0,48 \\
\hline \multicolumn{4}{|c|}{ Chăm sóc Cuff } \\
\hline$\leq 3$ lần/ngày $(*)$ & 1 & - & - \\
\hline >3 lần/ngày & 4,35 & $\begin{array}{l}1,146- \\
16,537\end{array}$ & 0,03 \\
\hline \multicolumn{4}{|c|}{ Chăm sóc hệ thống dây dân máy thở } \\
\hline < 3 lần/ngày $(*)$ & 1 & - & - \\
\hline > 3 lần/ngày & 1,41 & $\begin{array}{c}0,304- \\
6,575\end{array}$ & 0,66 \\
\hline \multicolumn{4}{|c|}{ Chăm sóc vệ sinh răng miệng } \\
\hline$\geq 2$ lần/ngày $(*)$ & 1 & - & - \\
\hline < 2 lần/ngày & 0,45 & $\begin{array}{c}0,077- \\
2,577\end{array}$ & 0,36 \\
\hline \multicolumn{4}{|c|}{ Số lân thay đối tư thế } \\
\hline 2 lần/ngày $(*)$ & 1 & & - \\
\hline > 2 lần/ngày & 3,37 & $\begin{array}{l}0,907- \\
12,534\end{array}$ & 0,07 \\
\hline \multicolumn{4}{|c|}{ Chăm sóc sonde tiếu dân lưu } \\
\hline$\leq 1$ lần/ngày $(*)$ & 1 & - & - \\
\hline > 1 lần/ngày & 1,62 & $\begin{array}{l}0,126- \\
20,944\end{array}$ & 0,71 \\
\hline \multicolumn{4}{|c|}{ Vô rung liệu pháp hô hấp } \\
\hline Không $(*)$ & 1 & - & - \\
\hline $\begin{array}{l}\text { Có (vô rung cách } \\
\text { quãng) }\end{array}$ & 4,93 & $\begin{array}{l}1,345- \\
18,063 \\
\end{array}$ & 0,01 \\
\hline \multicolumn{4}{|c|}{$\begin{array}{l}\text { GDSK cho gia đình NB về tình trạng bệnh, } \\
\text { kiến thức phòng }\end{array}$} \\
\hline$\leq 1$ lần/ngày $(*)$ & 1 & - & - \\
\hline > 1 lân/ngày & 1,83 & $\begin{array}{l}0,224- \\
15,008\end{array}$ & 0,57 \\
\hline \multicolumn{4}{|c|}{ GDSK cho gia đình NB về chế độ dinh dưỡng } \\
\hline > 1 lần/ngày $(*)$ & 1 & : & - \\
\hline$\leq 1$ lần/ngày & 0,59 & $\begin{array}{l}0,095- \\
3,590\end{array}$ & 0,58 \\
\hline \multicolumn{4}{|c|}{ GDSK cho gia đình NB về TH nội quy BV } \\
\hline > 1 lần/ngăy $(*)$ & 1 & & - \\
\hline s 1 lần/ngày & 1,04 & $\begin{array}{l}0,120- \\
8,983\end{array}$ & 0,97 \\
\hline
\end{tabular}

Nhận xét: Sau khi phân tích hồi quy đa biến, chỉ có yếu tố vố rung liệu pháp hô hấp và chăm sóc cuff có mối liên quan với kết quả chăm sóc $(p<0,05)$.

\section{BÀN LUÂN}

Nghiên cứu được thực hiện trên nhóm đối tượng người bệnh ngộ độc cấp điều trị thở máy.
Đây là những đối tượng cần được chăm sóc đặc biệt và duy trì đường thở, trong đó việc chăm sóc máy thở và dự phòng điều trị các biến chứng liên quan đến thở máy đóng vai trò quan trọng trong việc đảm bảo hiệu quả điều trị. Việc điều dưỡng sát sao người bểnh, cũng như có tẩn suất chăm sóc nhiều lần trong ngày thì người bệnh sẽ được hưởng lợi và sẽ có thể trang tốt hơn.

Kết quả nghiên cứu của chúng tôi cho thấy, người bệnh chủ yếu được chăm sóc răng miệng 1 lần/ngày $(78,5 \%$ lúc vào viên và $75,6 \%$ lúc ra viên), số bênh nhân được chăm sóc răng miệng trên hoặc bằng 2 lần/ ngày chỉ chiếm 21,5\%. Có $10,2 \%$ người bệnh cần chăm sóc vết loét da, trong đó có $4,4 \%$ được chăm sóc $>2$ lần/ngày. Tỷ lệ người bệnh vỗ rung liệu pháp hô hấp cách quãng 2 h/lân là $70,4 \%$ khi nhập viện và $94,8 \%$ khi ra viện/chuyển khoa, tỷ lệ người bệnh không được vố rung liệu pháp hổ hấp cách quãng chiếm 29,6\%. Lý giải cho tỷ lê người bênh không được vỗ rung liệu pháp hô hấp là do bênh nhân lọc máu liên tục nên hạn chế rất nhiều kỹ thuật chăm sóc này. Có $91,1 \%$ có nằm đệm hơi khi vào viên và tỷ lệ này là $95,6 \%$ khi ra viện/ chuyển khoa, một số bệnh nhân không được nằm đệm hợ là do tình trạng ngộ cấp nhẹ, tiển lương nằm thở máy ngắn mà đặt $\mathrm{NKQ}$ chủ yếu để bảo vệ đường thở chống sặc phổi. Phần lớn gia đình người bệnh $(84,4 \%)$ được giáo dục sức khỏe về tình trạng bệnh, kiến thức phòng chống tái ngộ độc là trên 2 lần/ngày khi vào viện và 95,6\% khi ra viện/chuyển khoa. Tỷ lệ gia đình người bệnh được giáo dục sức khỏe về chế độ dinh dưỡng trên 2lần/ngày khi vào viện là $78,5 \%$ và $94,9 \%$ khi ra viên/ chuyển khoa. Có $91,2 \%$ gia đình được giáo dục về nội quy bênh viện $>2$ lần/ngày khi vào viện và $97,1 \%$ khi ra viện/ chuyển khoa. Việc giáo dục sức khỏe về kiến thức phòng ngộ độc trở lại cũng như dinh dưỡng, nội quy khoa phòng bềnh viện là điều vô cùng quan trọng, và đặc biệt là kiến thức phòng ngộ độc trở lại khi người bệnh tái sinh hoạt tại cộng đồng.

Với những hoạt động được ghi nhận, kết quả nghiên cứu của chúng tôi cho thấy, khi ra viện/chuyển khoa, tỷ lệ người bệnh có kết quả chăm sóc tốt là $85,2 \%$; chưa tốt là $14,8 \%$. Mô hình hồi quy cho thấy yếu tố vỗ rung liệu pháp hô hấp và chăm sóc Cuff có mối liên quan với kết quả chăm sóc $(p<0,05)$. Người bệnh thở máy có tình trạng phần dịch đờm ứ đọng trong phổi, đường thở, dẫn tới tắc nghẽn đường thở hoặc dế bị nhiếm khuẩn đường thở. Vỗ rung giúp làm tăng hiệu quả điều trị bệnh hô hấp, cải thiện chức 
năng phổi, giảm các biến chứng và thời gian nằm viện. Chăm sóc cuff thường xuyên sẽ giúp giảm nguy cơ nhiễm khuẩn. Beccaria LM và cộng sự (2017) cũng khuyến nghị theo dõi Cuff từ 2 lần/ngày trở lên [3]. Kiều Văn Khương (2019) bệnh viện Quân Y 103 đề cập trong nghiên cứu sự biến đổi áp lực trong bóng cuff ống nội khí quản ở bện nhân thở máy tại khoa Điều trị tích cực. Nghiên cứu cho thấy việc theo dõi áp lực cuff ở người bệnh thở máy là rất cần thiết [4].

Bệnh nhân được đặt nội khí quản có hút trên cuff và theo dõi áp lực hút trên cuff liên tục có tác dụng làm giảm nhiễm khuẩn phổi và hạn chế nguy cơ nhiễm khuẩn phổi. Điều này cho thấy cần gia tăng công tác theo dõi, chăm sóc như: chăm sóc Cuff đảm bảo đủ áp lực hay vỗ rung liệu pháp hô hấp, dẫn lưu tư thế kết hợp sử dụng ống NKQ có hút trên cuff có thể làm tăng kết quả chăm tốt nhất cho công tác chăm sóc của điều dưỡng với người bệnh ngộ độc cấp thở máy. Điều này phù hợp với gói chằm sóc người bệnh thở máy chung mà bệnh viện Bạch Mai đã và đang áp dụng tại các đớn vị Hồi sức. Kết quả của chúng tôi phù hợp với nghiên cứu của một số tác giả trong nước khi nghiên cứu tại một số đơn vị hồi sức [5], [6], [7].

\section{KẾT LUẬN}

Người bệnh ngộ độc cấp có thở máy tại Trung tâm Chống độc Bệnh viện Bạch Mai có kểt quả chăm sóc tốt là $85,2 \%$, chưa tốt $14,8 \%$.

Chăm sóc điều dưỡng có vai trò quan trọng trong công tác chăm sóc người bệnh thở máy. Người bệnh được vỗ rung, lý liệu pháp hô hấp, chăm sóc cuff tích cực cho kết quả chăm sóc tốt hơn. Chăm sóc vỗ rung liệu pháp hô hấp tích cực có khả năng tăng kết quả chăm sóc tốt cao gấp 4,93 lần $(\mathrm{OR}=4,93, \mathrm{p}<0,05)$ so với việc không thực hiện vỗ rung. Chăm sóc cuff > 3 lần/ngày có khả năng kêt quả chăm sóc ở mức tốt cao gấp 4,35 lần $(O R=4,35, p<0,05)$ so với việc chăm sóc với tần suất $\leq 3$ lần/ngày $(p<0,05)$.

\section{TÀI LIÊU THAM KHẢO}

1. Hà Trân Hưng và Hà Thị Bích Vân (2015), "Nguyên nhân các ngô đôcc cấp có rối loạn ý thức taii Trung tâm chống độc bệnh viện Bạch Mai", Tạp chí Nghiên cứu y học. $97(5)$, tr. 99.

2. Bộ Y tế (2018), Niên giám thống kê $Y$ tế 2018, Bổ Y tế, Hà Nô̂i.

3. Beccaria L. M., et al. (2017), "Tracheal cuff pressure change before and after the performance of nursing care", Rev Bras Enferm. 70(6), 1145-1150.

4. Kiêuu Văn Khương (2018), "Nghiên cứu sư biến đổi áp lực trong bóng cuff ống nội khí quản ở bệnh nhân thở máy tại khoa Điều trị tích cực, bệnh viện Quân Y 103", Tạp chí Y dược lâm sàng 108. 14(4), tr. 49-54.

5. Đào Ngọc Sơn (2016), Thực trạng nhiễm khuẩn bệnh viện trên bệnh nhân thở máy tại khoa Hồi sức cấp cứu bệnh viện Nhiệt Đới trung ương, Khoa Chống Độc bệnh viện Bạch Mai và một số yếu tố liên quan, năm 2016, Khóa luận tốt nghiệp Cử nhân Điều dưỡng, Trướng Đại học Thăng Long.

6. Trân Thị Tuệ Tú (2019), Thực trang chăm sóc người bệnh thở máy và các yếu tố liên quan đến nhiễm khuẩn bệnh viện tại các khoa lâm sàng Bệnh viện Bạch Mai năm 2019, Luận văn Thạc sỹ Điều dướng, Trường Đại học Thăng Long.

7. Vũ Thị Yến (2014), Tỷ lệ viêm phổi thở máy ở bênh nhân thơ máy được điểu trị ở một số khoa tai bệnh viện Bạch Mai, năm 2014 và một số yếu tố liển quan, Khóa luận tốt nghiệp Cử nhân Điều dưỡng, Trường Đại học Thăng Long.

\section{NGHIÊN CỨU TÁC DỤNG SINH CYTOKIN CỦA KHỐI TẾ BÀO CAR-T}

\section{TÓM TẮT}

Mục tiêu: Nghiên cứu đánh giá khả năng sinh IL2, TNF-a và IFN-Y của các tế bào CAR-T khi đồng nuôi cấy với các dòng tế bào ung thư $C D 19+$. Phương pháp NC: Khả năng sinh các interleukin khi nuôi cây

\footnotetext{
${ }^{1}$ Học viện quân y

Bềnh viên Quân y 103

Chịu trách nhiệm chính: Cấn Văn Mão

Email: canvanmao2011@gmail.com

Ngày nhân bài: 4.01.2021

Ngày phản biên khoa học: 9.3.2021

Ngày duyệt bài: 16.3.2021
}

\section{Cấn Văn Mão ${ }^{1}$, Đặng Thành Chung ${ }^{1}$, Ngô Thu Hằng ${ }^{1}$ Nguyễn Văn $\mathrm{Ba}^{2}$}

khối tế bào CAR-T với các tế bào ung thư (tế bào K562, Daudi, 1D2, PBMC) được đánh giá ở hai thời điểm sau 24 và 48 giờ. IL-2, TNF-a và IFN-y được định lượng bằng các bộ sinh phẩm IL-2 Human ELISA Kit, TNF alpha Human ELISA Kit, IFN gamma Human ELISA Kit (Thermo Fisher Scientific). Kết quả: tại cả hai thời điểm 24 giờ và 48 giờ nông độ các cytokine IFN-y, IL-12, TNF-a trong dịch nuôi cấy của tế bào CAR-T khi nuôi cấy với các tế bào ung thư có CD19+ đều cao hơn có ý nghĩa thống kê $(p<0,05)$ so với nồng độ IFN- $y$, IL-12, TNF-a trong dịch nuôi cấy của tế bào trên với tế bào PBMC (nhóm chứng). Ngoài ra, nồng độ các cytokine trên trong dịch nuôi cây của tế bào CAR-T khi nuôi cấy với các tế bào ung thư có 